\title{
Enhancement Punching Shear in Flat Slab Using Mortar Infiltrated Fiber Concrete
}

\author{
Ali Sabah Imran Shwalia ${ }^{a^{*}}$, Nabeel Hasan Ali Al-Salim ${ }^{\text {a }}$, Haider M. Al-Baghdadi ${ }^{\text {a }}$ \\ ${ }^{b}$ College of Engineering, University of Babylon, Hilla, Babil, Iraq.
}

Received 23 March 2020; Accepted 29 June 2020

\begin{abstract}
In this paper, improving the punching shear of slab column connection using mortar infiltrated fiber concrete is studied. Eight specimens of reinforced concrete slabs identical in dimension and reinforcement were tested, six of them were casting with hybrid concrete (normal strength concrete and mortar infiltrated fiber concrete) and two specimens were cast with normal strength concrete as control specimens. All specimens were tested under vertical loading. The mortar infiltrated fiber concrete was cast monolithically with the normal strength concrete at different thickness at one and a half times of the effective depth (1.5d) at the center of the slab, once at all the thickness of cross section of the slab and the others at half thickness either tension or compression face of the slabs all cases cast with two types of fiber. The vertical load was applied upward through a square column with a dimension of $(100 \mathrm{~mm})$. In all slabs, no failure in mortar infiltrated fiber concrete was observed. The test results showed that the use of mortar infiltrated fiber concrete improves the punching shear strength for some cases according to the type of fibers and the location of casting mortar infiltrated fiber concrete in slabs. The enhancement in punching shear strength due to using mortar infiltrated fiber concrete at $1.5 \mathrm{~d}$ square shape $(265 \mathrm{~mm})$ ranged from $4 \%$ to $46 \%$ compared with the control specimens.
\end{abstract}

Keywords: Improvement Punching Shear; Mortar Infiltrated Fiber Concrete; Hybrid Concrete.

\section{Introduction}

The flat plate slab is susceptible to punching shear failure. This type of failure is catastrophic because no visible signs are shown before failure. There are actually specific punching shear strength formulas for slab column connections such as those suggested by ACI 318 [1] and BS 8110 [2] codes. These formulas were developed for slab casted using normal strength concrete; so, they might not be applicable to strengthened slab using mortar infiltrated fiber concrete. The classical strengthening techniques using to avoiding sudden punching failure, include the use of transverse pre-stressed reinforcement, steel plates and bolts, increase the thickness of the slab around column or use of a larger column cross-section and use of an epoxy bonding steel plate. Further focus has been given to use advanced composite materials to strengthen especially fibers in all different types, to prevent sudden punching shear failure. In this study using the mortar infiltrated fiber concrete as a strengthening martial. Mortar infiltrated fiber concrete is a comparatively modern material differentiated from Fiber Reinforced Concrete (FRC) in two aspects that is fiber volume fraction and manufacturing process.

Mortar infiltrated fiber concrete was developed to incorporating large amounts of fibers in cement composites, to get a very high strength property. The researchers began to use a large variety of fibers. Mortar infiltrated fiber concrete has high strength as well as large ductility and far significant potential for structural applications [3-7]. The

* Corresponding author: alishwalia@yahoo.com

http://dx.doi.org/10.28991/cej-2020-03091560

(c) 2020 by the authors. Licensee C.E.J, Tehran, Iran. This article is an open access article distributed under the terms and conditions of the Creative Commons Attribution (CC-BY) license (http://creativecommons.org/licenses/by/4.0/). 
matrix does not contain coarse aggregate which, of course, cannot infiltrate through the tiny spaces between dense fibers network, but has a high cements content. However, it may contain fine or extra-fine sand and additives such as silica fume, fly ash, and slag. The mortar fineness must be designed to properly infiltrate the dens fiber layer placed in mold. Limited research work has been carried out on using mortar infiltrated fiber concrete to improving punching shear, and all of this study depending on cast all the slab with mortar infiltrated fiber concrete [8-10], but this way not economical due to the need for large quantities of fiber. Therefore, in this study, work will be done to improve the normal strength concrete slabs by using small quantities of mortar infiltrated fiber concrete as a hybrid slabs, to obtaining good results with great economy. The influence of the variables studied in this study covers the thickness and position of mortar infiltrated fiber concrete and the type of fiber used.

\section{Materials and Methods}

The experimental work includes initialization and test of raw materials and making trail mixes right up to the required mix of normal concrete and mortar after that eight slabs were cast for test them and studying the effect of using mortar infiltrated fiber concrete. Figure 1 show the flowchart for the experimental work.

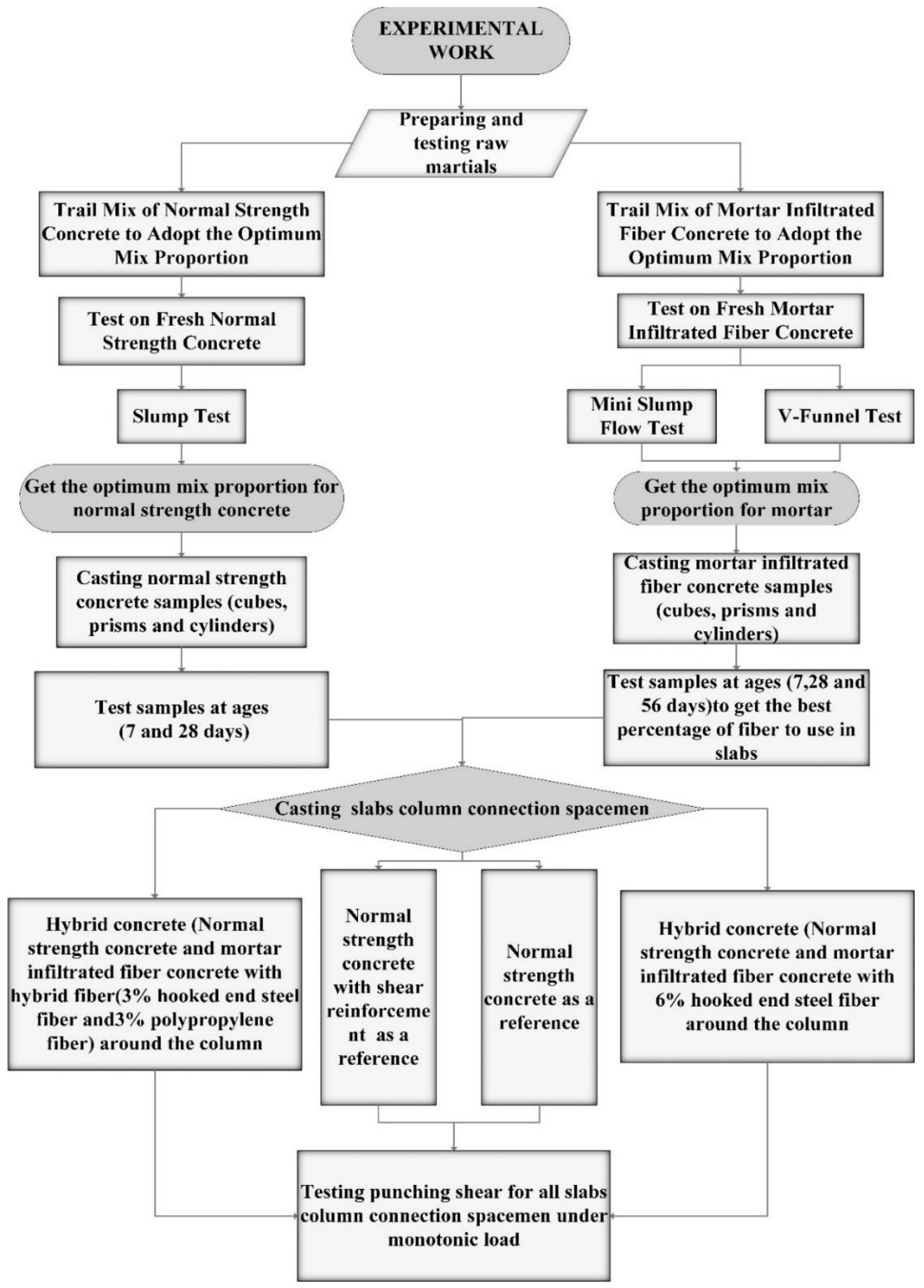

Figure 1. Experimental program flow chart 


\subsection{Materials Used for Cast Specimens}

For the slab specimens, two types of concrete used normal strength concrete mixtures with compressive strengths of $25 \mathrm{MPa}$ and the other type are mortar infiltrated fiber concrete with two types of fiber (steel fiber and hybrid fiber) with compressive strengths getting from trail mix (92 and $62 \mathrm{MPa}$ ) Sequentially [11].

\subsubsection{Materials Used for Preparing Normal Strength Concrete}

The normal strength concrete was design according to American method of mix proportions selection (ACI Committee 211.1-91) [12]. The target concrete strength f'c was $25 \mathrm{MPa}$.

\section{Cement}

In this study the type of cement used was limestone Portland cement (CEM II/A-L- 42.5 R) mate with the (IQS No. 5/1984) limitations [13].

\section{Fine Aggregate}

Natural local sand conforms to the limits of Iraq specification (IQS No.45/1984) [13], Zone (2). Figure 2 shows the grading curve of the natural sand after sieving.

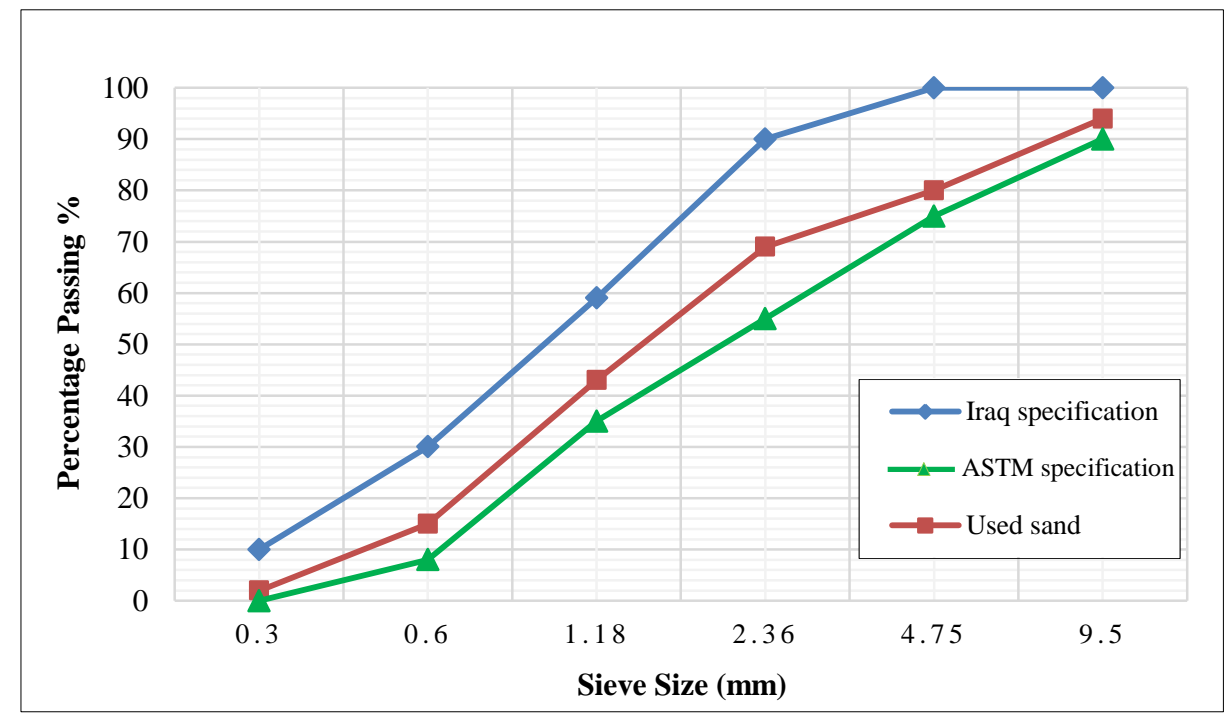

Figure 2. Grading curves for fine aggregate

\section{Coarse Aggregate}

Natural rounded gravel with a maximum size of $10 \mathrm{~mm}$ as shown in the grading curve used as the coarse aggregate in this work. Mechanical and chemical properties meet the requirements of (ASTM C33 /86) [14]. The grading curve of the natural gravel shown in Figure 3.

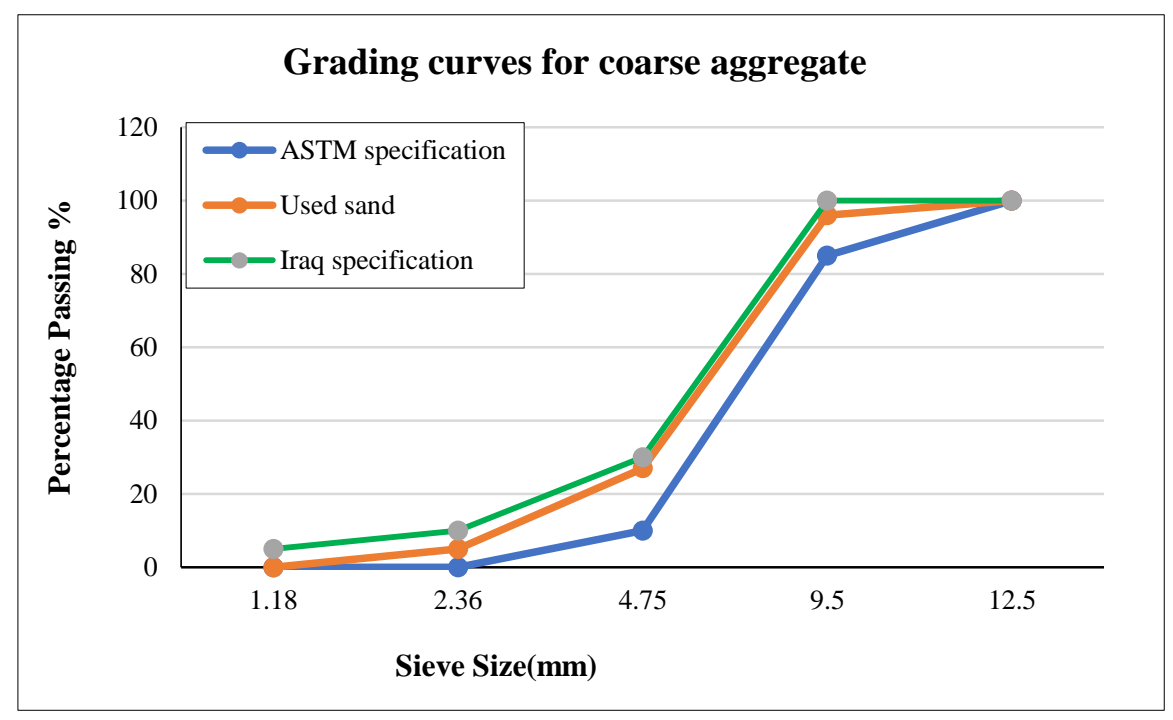

Figure 3. Grading curves for coarse aggregate 


\subsubsection{Materials Used for Preparing Mortar Infiltrated Fiber Concrete}

In the experimental study, many trail mortar mixtures were performed to find the correct mixing proportions and with the assistance of some previous studies [15-17].

\section{Cement}

In this study the type of cement used was limestone Portland cement (CEM II/A-L- 42.5 R) mate with the (IQS No. 5/1984) limitations [13].

\section{Extra Fine Sand}

Natural local sand was used as a fine aggregate. Only extra fine sand, which was sieve through (600 $\mu \mathrm{m})$ to separating the coarser particles used in preparing mortar. It conforms to the limits of Iraq specification No.45/1984 [13], Zone (3). Figure 4 shows the grading curve after sieving process.

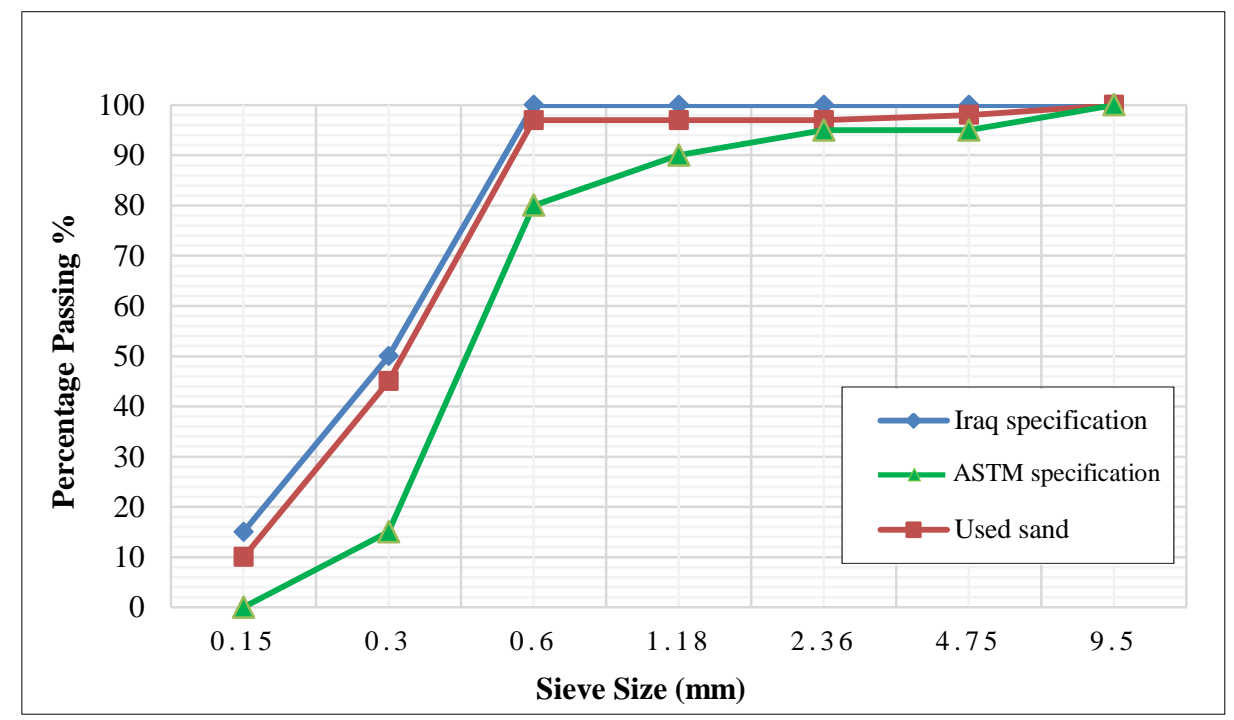

Figure 4. Grading curves for extra fine aggregate

\section{Micro Silica Fume (SF)}

In this work the silica fume used was commercially known as Mega Add MS (D) from the chemical company (CONMIX), with the replacement (10\%) by weight of cement.

\section{High-Range Water Reducing Admixture (HRWRA)}

The high range water reducing admixture was used in this work for the preparation of mortar, known commercially as (Hyperplast PC200). It is factory by the company (DCP), and meets with the (ASTM C494/C494 M) requirements [18].

\section{Fibers}

In this work two different types of fibers were used. The first type was hooked end steel fibers with a length of (30 $\mathrm{mm})$, a diameter of $(0.5 \mathrm{~mm})$ and the tensile strength of about $1100 \mathrm{MPa}$, the hooked fiber was supplied from JATLAS Company in Turkey. The second type was synthetic polypropylene fiber with a length of (27 mm), a diameter of $(27 \mathrm{~mm})$ and with a tensile strength of $570-660 \mathrm{MPa}$, this type of fiber was manufactured by the FORTA FERRO Company in U.S.A. The two types of fibers following the ASTM A820/A820M-04[19]. Figure 5 shows the two types of used fibers.
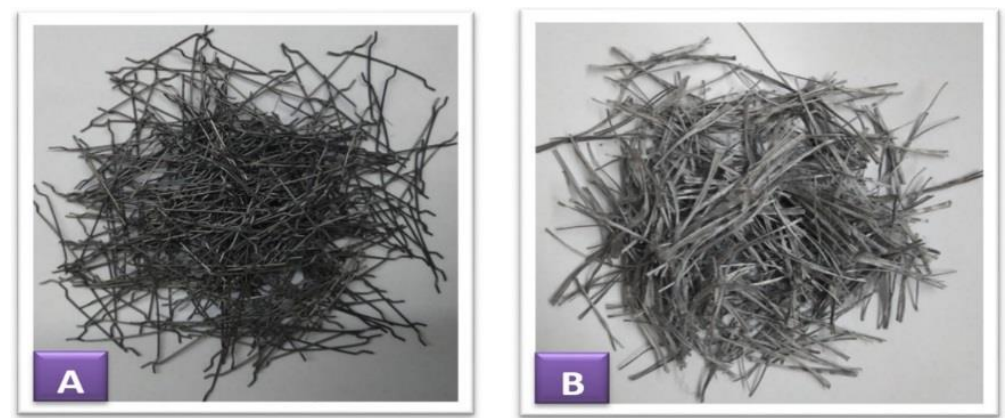

Figure 5. The fibers used: A- end hooked steel fiber, B- polypropylene fiber 


\subsubsection{Reinforcing Steel}

Deformed steel bars with two different diameters were used in the specimens. Uniaxial tension tests were carried out on the $(10$ and $6 \mathrm{~mm})$ nominal diameter bars to determine the yielding stress and the ultimate strength. Reinforced steel bars diameter $10 \mathrm{~mm}$ with a yield stress of $554 \mathrm{MPa}$ was used to be flexural reinforcement of the flat slab, while $6 \mathrm{~mm}$ in diameter bars with a yield stress of 560 was used in column stirrups. Three samples were tested for each bar diameter and the average of the results was used. The test samples were placed in a computerized tensile test machines and tested until ruptures, according to ASTM A615 [20].

\subsection{Specimens Casting Process}

Eight slabs specimens with the dimensions of $(900 \times 900 \times 80) \mathrm{mm}$ with a square column in the middle of the slab with dimension $(100 \times 100 \times 200) \mathrm{mm}$ were cast. Before casting, the selection materials were prepared and weighed according to the results obtained from the trail mixes as shown in Table 1. The mortar was mixed by electrical drill mixer with a suitable pan about $\left(0.02 \mathrm{~m}^{3}\right)$ capacity, mixing time about $(7-9)$ minutes. Before mixing operation, the pan was cleaned off. The binder material (cement and silica fume) were mixed in the pan to disperse the silica fume particles throughout the cement particles. Then the sand was added and the mixture was mixed to get a uniform dry mixture. The whole amount of high-range water-reducing admixture (Hyperplast PC9200) was mixed separately with (1/3) of mixing water, after that, (2/3) of mixing water was added to the mix, then HRWR with $(1 / 3)$ of mixing water was fed to the mixer to obtain the required fluidity [21]. At the same time, the mixing procedure of normal strength concrete start by mixing the gravel with the dry sand in the electrical horizontal rotary drum mixer of $\left(0.09 \mathrm{~m}^{3}\right)$ volume capacity and mixed for several minutes. Then added cement to the mixer, and gradual adding the weighted water to the mix. The mixing time is total about ( $8-10$ minutes).

Table 1. The optimal mixing proportions for normal strength concrete and mortar infiltrated fiber concrete for $1 \mathbf{m}^{3}$

\begin{tabular}{|c|c|c|c|c|c|}
\hline \multirow[b]{3}{*}{ Materials } & \multirow[b]{3}{*}{$\begin{array}{c}\text { Proportions of mix } \\
\left(\mathrm{kg} / \mathrm{m}^{3}\right)\end{array}$} & \multicolumn{4}{|c|}{ Mortar infiltrated fiber concrete } \\
\hline & & \multicolumn{2}{|c|}{ Hooked end steel fiber } & \multicolumn{2}{|c|}{ Hybrid fibers } \\
\hline & & Materials & $\begin{array}{c}\text { Proportions of mix } \\
\left(\mathrm{kg} / \mathrm{m}^{3}\right)\end{array}$ & Materials & $\begin{array}{c}\text { Proportions of mix } \\
\left(\mathrm{kg} / \mathrm{m}^{3}\right)\end{array}$ \\
\hline Cement & 368 & Cement & 872.1 & Cement & 872.1 \\
\hline Gravel & 900 & Sand & 969 & Sand & 969 \\
\hline Sand & 850 & Silica Fume $10 \%$ rep & 96.9 & Silica Fume $10 \%$ rep & 96.9 \\
\hline Water & 208 & Hooked end Steel Fiber & 471.9 & $\begin{array}{c}\text { Hooked end Steel Fiber } \\
\text { Polypropylene fiber }\end{array}$ & $\begin{array}{c}235.95 \\
27.3\end{array}$ \\
\hline $\mathrm{W} / \mathrm{C}$ ratio & 0.57 & $\begin{array}{c}\mathrm{W} / \mathrm{b} \\
\text { Super Plasticizer by wt. of } \\
\text { Cementous }(\%)\end{array}$ & $\begin{array}{c}0.32 \\
2.4\end{array}$ & $\begin{array}{c}\mathrm{W} / \mathrm{b} \\
\text { Super Plasticizer by wt. of } \\
\text { Cementous }(\%)\end{array}$ & $\begin{array}{l}0.32 \\
2.4\end{array}$ \\
\hline
\end{tabular}

All slabs used in this work were cast in plywood molds with clear dimensions $(900 \times 900 \times 80 \mathrm{~mm})$, and steel mold for isolation and limit the area will be cast with mortar infiltrated fiber concrete square shape with dimension $(265 \times 265 \mathrm{~mm})$ have a clear height $(80 \mathrm{~mm})$. The reinforcing bar ratio constant with $(\rho=0.0158)$ and the concrete cover for reinforcing bars was $15 \mathrm{~mm}$ for all slabs. The two types of concrete casting together to achieve the bonding between the two types of concrete. The casting process is defined according to the following stages:

1. Before each casting, the plywood and steel molds were prepared by cleaning and lightly lubricating the internal faces by oil to prevent adhesion with hardened concrete and placed on horizontal ground.

2. After preparing the molds, put the pre-equipped reinforcing steel and centering it with cover $15 \mathrm{~mm}$ with all directions then connect the reinforcing steel of the column in the center of the slab as shown in Figure 6.
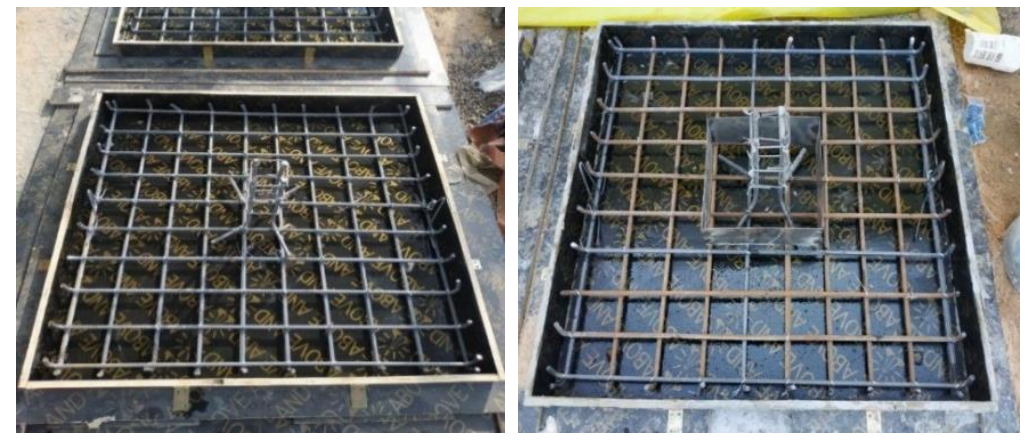

Figure 6. Preparing molds and steel reinforcement 
3. Normal strength concrete preparing as mentioned previously, after many trails of casting mortar infiltrated fiber concrete technique in the laboratory, multi-layers technique was used for incorporating the steel fiber into the mortar matrix. The multi-layers technique involved initial placing and packing the fibers inside the steel mold as shown in Figure 7 A, which were oriented randomly, followed by filling the mold by the mortar up to this level as shown in Figure $7 \mathrm{~B}$. The mortar has to be flowable enough to ensure infiltration through the fiber. At the same time the normal strength concrete casting in the plywood mold around the steel mold reaching to the required level.
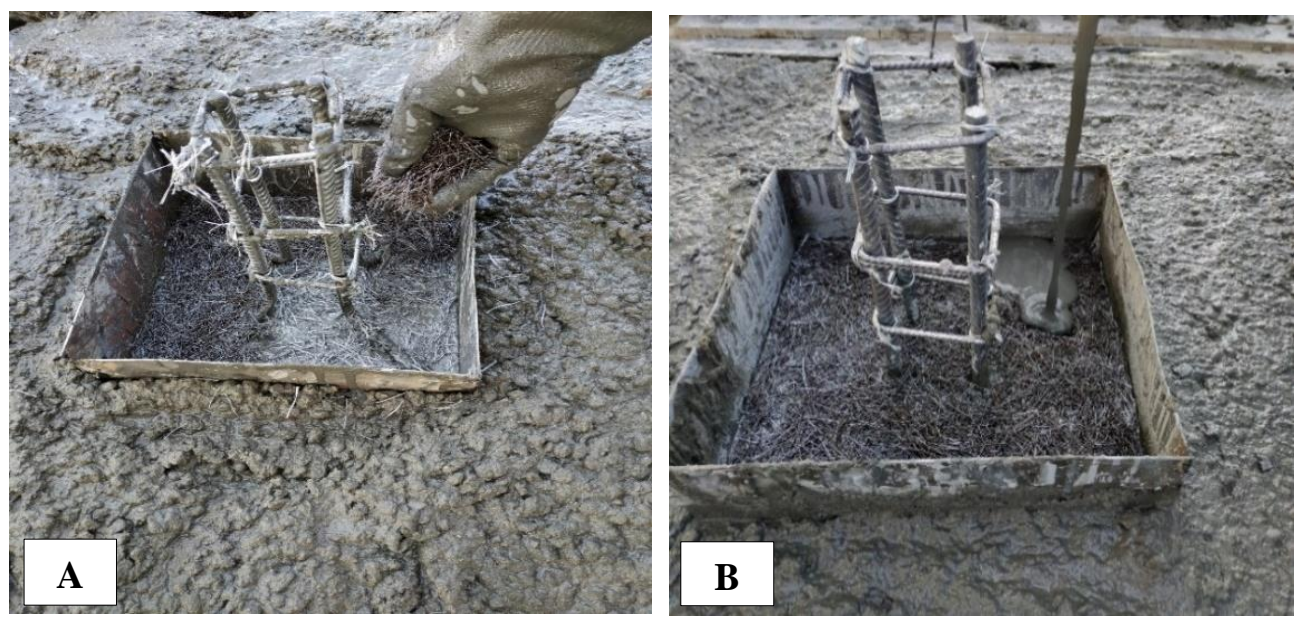

Figure 7. A: Spread the fiber by multi-layers technique. B: Pour the mortar after complete the layer of fiber

4. The contents of mortar infiltrated fiber concrete in the steel mold were compacted using a steel rod with a diameter of $4 \mathrm{~mm}$ to avoid honeycombing or voids. This process was repeated (for each layer) where the entire mold was filled with the required volume fraction of fiber.

5. Soon after filled all molds (plywood and steel) to the same level as required the steel mold removed by a steady upward pull, then use vibration for normal strength concrete and around the area cast with mortar infiltrated fiber concrete to compact and achieve the bonding between the two types of concrete casting and, the specimens were leveled by hand trawling, and covered with polyethylene sheet in the laboratory for 24 hours to prevent evaporation of moisture from the fresh concrete.

6. The compressive strength was measured for each casting series by testing three standard concrete cubes with dimensions of $(100 \times 100 \times 100 \mathrm{~mm})$ for compressive strength of mortar infiltrated fiber concrete. And cubes $(150 \times 150 \times 150 \mathrm{~mm})$ for compressive strength of normal strength concrete. After (24) hours remove the plywood mold and cast the column using square steel mold with dimension $(100 \times 100 \times 200 \mathrm{~mm}$ height $)$ as shown in Figure 8, the column cast with normal strength concrete.

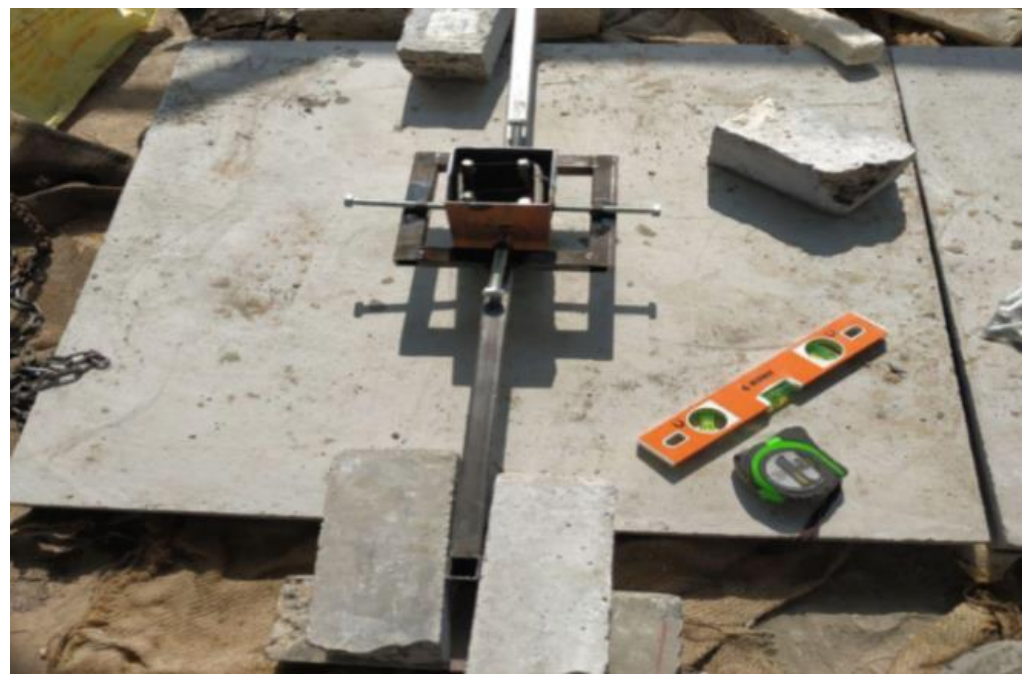

Figure 8. Preparing the column for casting with normal strength concrete

The conventional curing method was used to simulate the practical site conditions. Thereafter, slabs specimens were cured by saturated burlap and covering with a polyethylene sheet to prevent evaporation of curing water. 


\subsection{Test Setup and Procedure}

The tested specimens were simply supported at the four edges and loaded centrally through square column stubs with dimension of $100 \mathrm{~mm}$ sides with the height of $200 \mathrm{~mm}$ identical for all specimens. All slabs supported by a large reaction steel frame and tested using a hydraulic jack with maximum capacity of $600 \mathrm{KN}$ as shown in Figure 9. The deflection of the specimens at the center of the tension side of slabs was measured using a dial gage with capacity of $30 \mathrm{~mm}$. An electric pressure transducer was used to measure the applied load. The duration time for each of these tests was about 30 minutes.
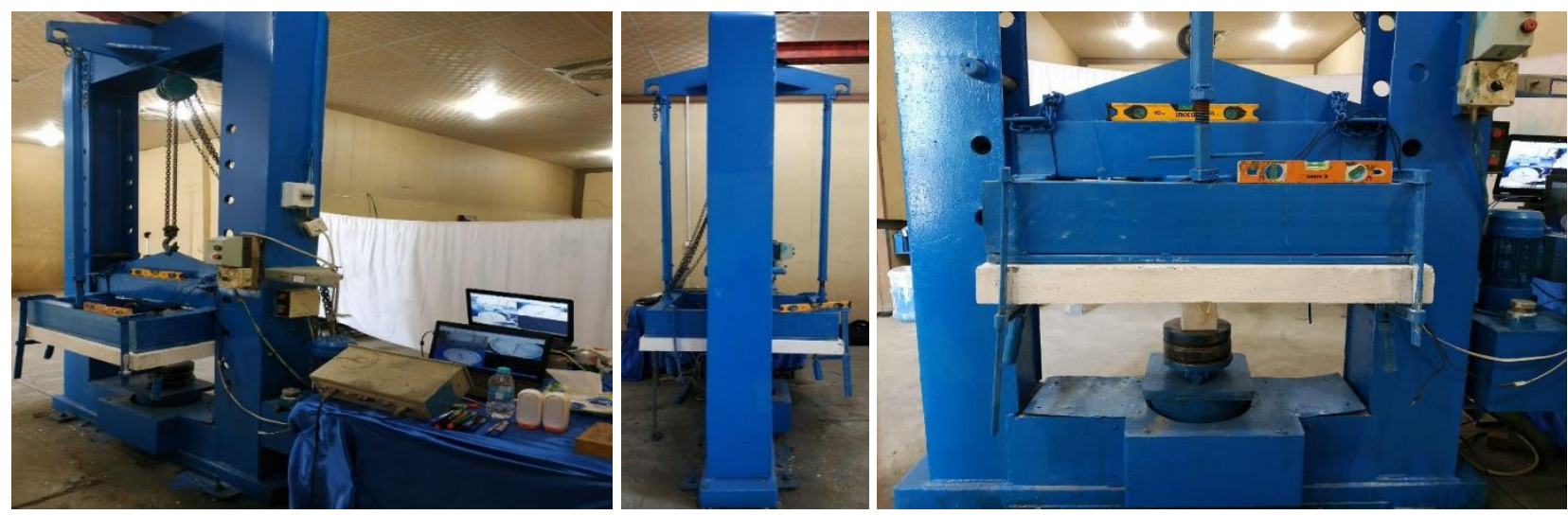

Figure 9. Method of testing specimens using the universal testing machine

\subsection{Description and Identification of the Tested Slabs Specimens}

To facilitate the comparison between the slabs, each slab specimen is identified by symbols as listed in Table 2 . Average of two specimens casting with normal strength concrete (N.S.C) only were tested as reference specimens. Other specimens were cast with N.S.C except the square area with the dimension of $265 \mathrm{~mm}$ in the middle of the slab that cast with mortar infiltrated fiber concrete with different thickness ( 80 and $40 \mathrm{~mm}$ ). Each case casting with two types of fiber (hooked end steel and hybrid fiber $50 \%$ hooked end steel with $50 \%$ synthetic polypropylene fiber).

Table 2. Specimens Identification

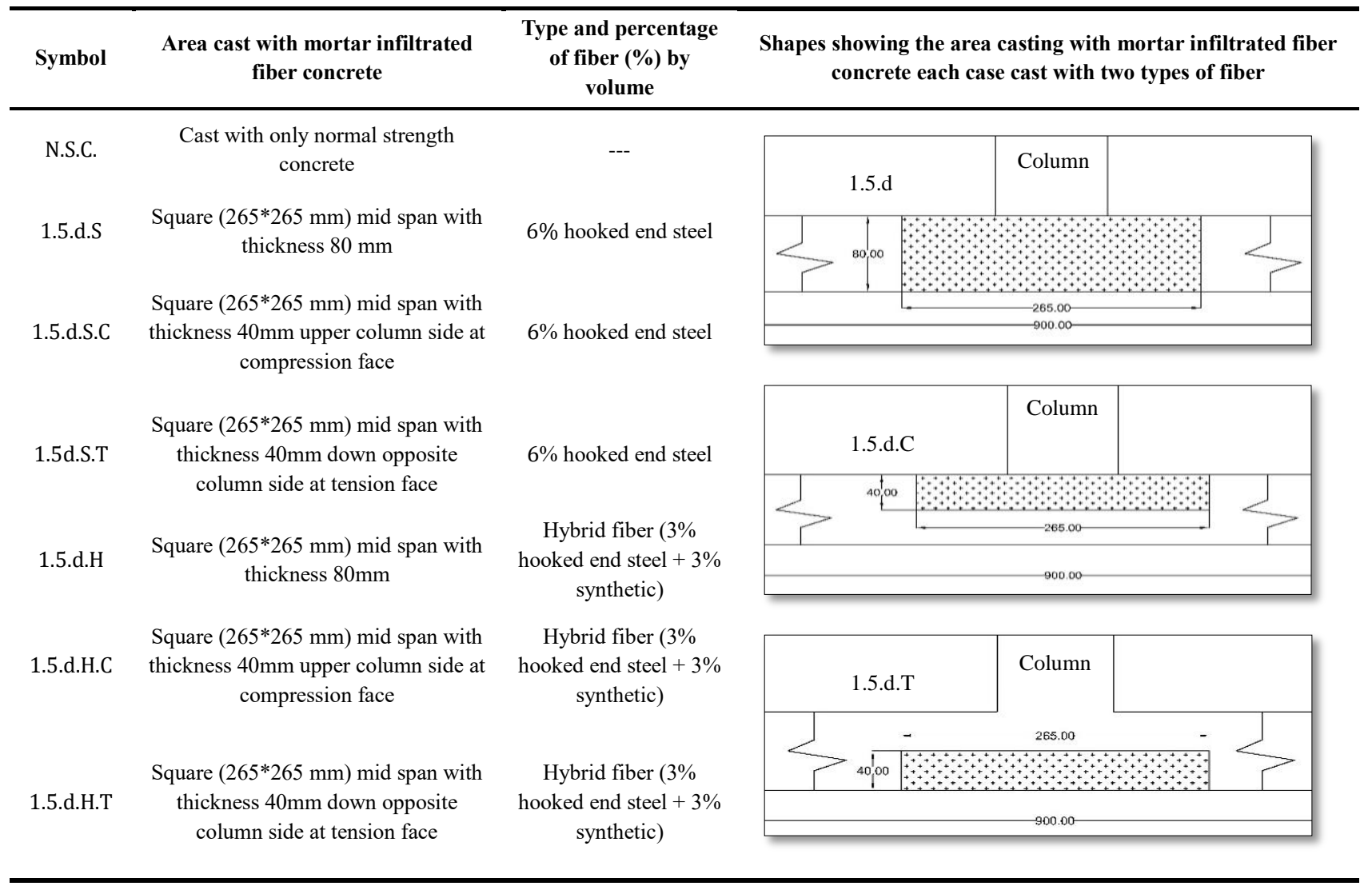




\section{Results and Analysis of Tests Specimens}

All eight specimens failed in punching shear with different ultimate load after relatively large deflection for some cases as shown in Table 3.

Table 3. The results of tested slabs

\begin{tabular}{|c|c|c|c|c|c|c|c|c|}
\hline specimen & $\begin{array}{c}\text { f'c for } \\
\text { N.S.C MPa }\end{array}$ & $\begin{array}{c}\text { f'c for } \\
\text { MIFC* MPa }\end{array}$ & $\begin{array}{l}\text { First crack } \\
\text { load KN }\end{array}$ & $\begin{array}{l}\text { Ultimate } \\
\text { load KN }\end{array}$ & $\begin{array}{c}\text { Max. } \\
\text { deflection mm }\end{array}$ & $\begin{array}{l}\text { Type of } \\
\text { failure }\end{array}$ & $\begin{array}{l}\text { Area of punching } \\
\text { shear } \mathbf{m m}^{2}\end{array}$ & $\begin{array}{c}\text { Increase in } \\
\text { punching load \% }\end{array}$ \\
\hline N.S.C * & 26.2 & --- & 38 & 114.3 & 5.3 & $\begin{array}{l}\text { Punching } \\
\text { Shear }\end{array}$ & 231953 & Reference \\
\hline $1.5 \mathrm{~d} . \mathrm{S}$ & 26.2 & 73.59 & 40 & 119.58 & 5.4 & $\begin{array}{l}\text { Punching } \\
\text { Shear }\end{array}$ & 304802 & 4.619 \\
\hline $1.5 \mathrm{~d} . \mathrm{H}$ & 26.2 & 49.39 & 41 & 149.38 & 7.1 & $\begin{array}{l}\text { Punching } \\
\text { Shear }\end{array}$ & 352757 & 30.691 \\
\hline 1.5d. S. C & 26.2 & 73.59 & 43 & 128.77 & 9 & $\begin{array}{l}\text { Punching } \\
\text { Shear }\end{array}$ & 355925 & 12.659 \\
\hline 1.5d. H. C & 26.2 & 49.39 & 42 & 167.04 & 9.45 & $\begin{array}{l}\text { Punching } \\
\text { Shear }\end{array}$ & 504124 & 46.141 \\
\hline $1.5 \mathrm{~d} . \mathrm{S} . \mathrm{T}$ & 26.2 & 73.59 & 40 & 114.48 & 5.4 & $\begin{array}{l}\text { Punching } \\
\text { Shear }\end{array}$ & 210625 & 0.157 \\
\hline 1.5d. H. T & 26.2 & 49.39 & 39 & 119.56 & 5.4 & $\begin{array}{l}\text { Punching } \\
\text { Shear }\end{array}$ & 265575 & 4.601 \\
\hline
\end{tabular}

* The value of N.S.C is the average of two specimen

* (MIFC) Mortar infiltrated fiber concrete

It is clear from the results that there is no improvement in the appearance of the first crack. In general, through the results, it was found that the use of mortar infiltrated fiber concrete improving punching shear in some cases according to the position of mortar and the type of fiber used. For the flexural steel reinforcement high significant effect on the punching shear resistance through the dual-action E. Rizk [22], since the ratio $\rho(0.0158)$ used is high compared to the $\rho \max (0.02)$ to control the type of failure and keep away from flexural failure. The thickness of the concrete cover with steel reinforcement reached about the half-thickness of slab (40) $\mathrm{mm}$. That show why some case of using mortar infiltrated fiber concrete don't have any effect on the ultimate load such as (1.5d S.T and 1.5d H.T) as shown in Figure 11. When the mortar infiltrated fiber concrete thickness is $40 \mathrm{~mm}$ at the tension face and not exceeded the flexural reinforcement, which led to no effect on punching shear because of the main reinforcement dual action in this region have enough resistance for punching shear. Also, for the same previously reason there was no improvement in the values of deflection comparing with the reference specimen as shown in Figure 12. The final shape and cracks of the two-above failure specimens shown in Figure 13.

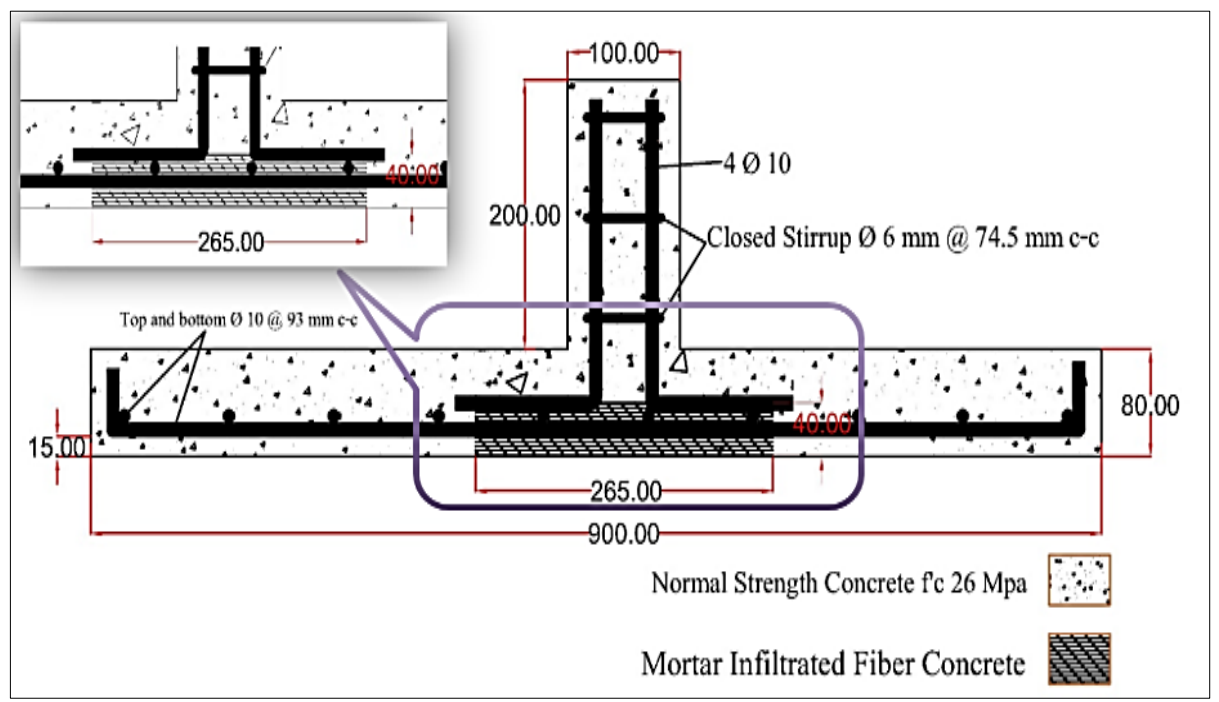

Figure 11. Cross section for slab showing the location of mortar infiltrated fiber concrete at the tension face 

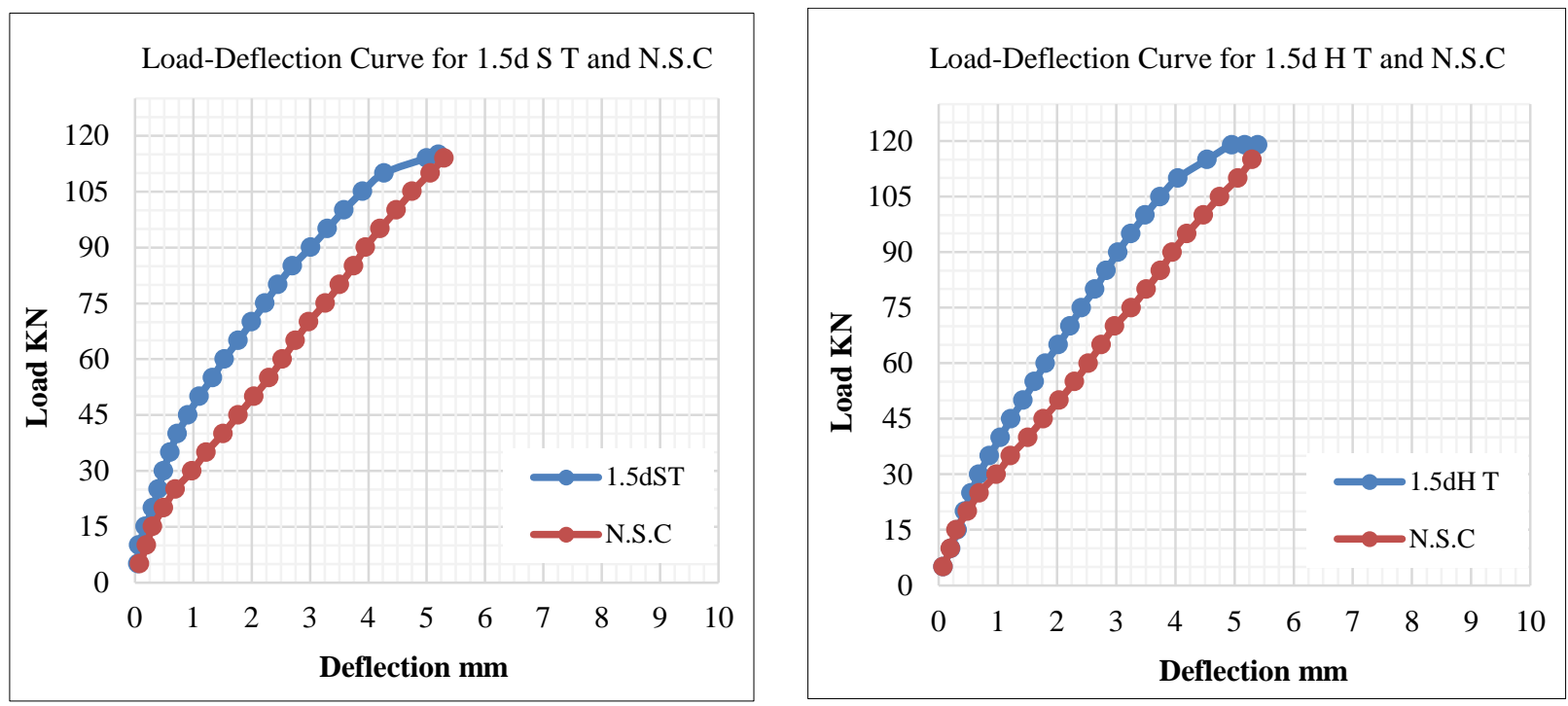

Figure 12. Load-Deflection curve for the two above cases compared with the reference
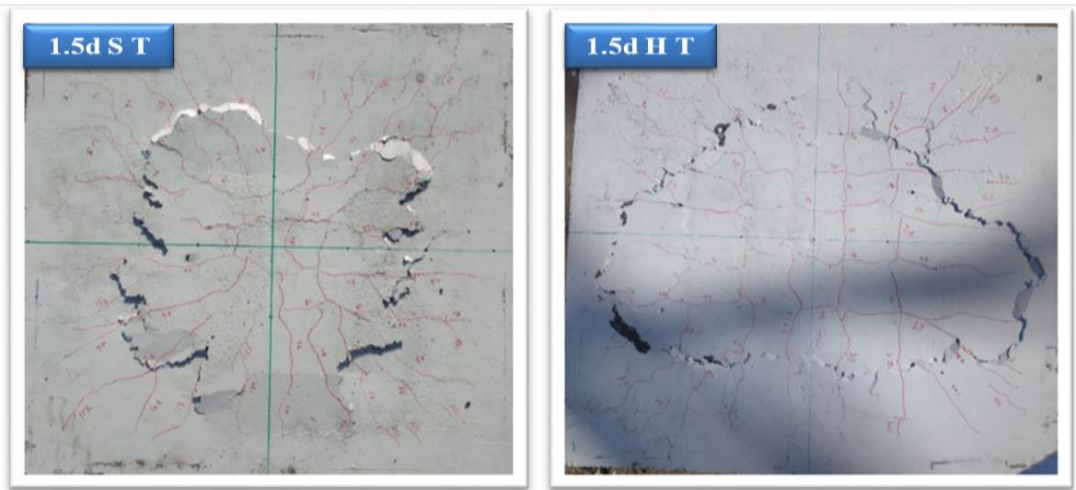

Figure 13. The final shape for tested slabs shows the crack pattern and punching perimeter

According to cases of $(1.5 \mathrm{~d} \mathrm{~S}$ and $1.5 \mathrm{~d} \mathrm{H})$, the mortar infiltrated fiber concrete was cast with $80 \mathrm{~mm}$ thickness as shown in Figure 14. The result depends on the type of fiber when using hybrid fiber as in this specimen (1.5d H) the ultimate load increase about $30 \%$ with respect to the reference this increase because of the good distribution of fiber at all the cross-section of mortar and this good spread of fiber led to increase in deflection about $34 \%$. While in case that cast with steel fiber $(1.5 \mathrm{~d} \mathrm{~S})$, the steel was isolated due to the effect of its high density. Figure 15 A explains the crosssection of failed prism in the test of modules of rapture (Fr). The high density of steel fiber led to descending to the bottom and irregular distribution within the cross-section and that its assembly was within the area of the main reinforcing steel. While using hybrid fiber, eliminates the phenomenon of steel fiber diving because of the difference in densities between steel fiber and mortar and using lightweight fiber like synthetic polypropylene work to provides a carrier layer for steel and prevent it from submergence and achieve a good distribution as shown in Figure 15 B. This shows why no improvement when using steel fiber only as in case $(1.5 \mathrm{~d} \mathrm{~S})$ and thus not giving any enhancement in the ultimate load and deflection with respect to the reference as shown in Figure 16. Figure 17 shows the final shape for the tested slabs.

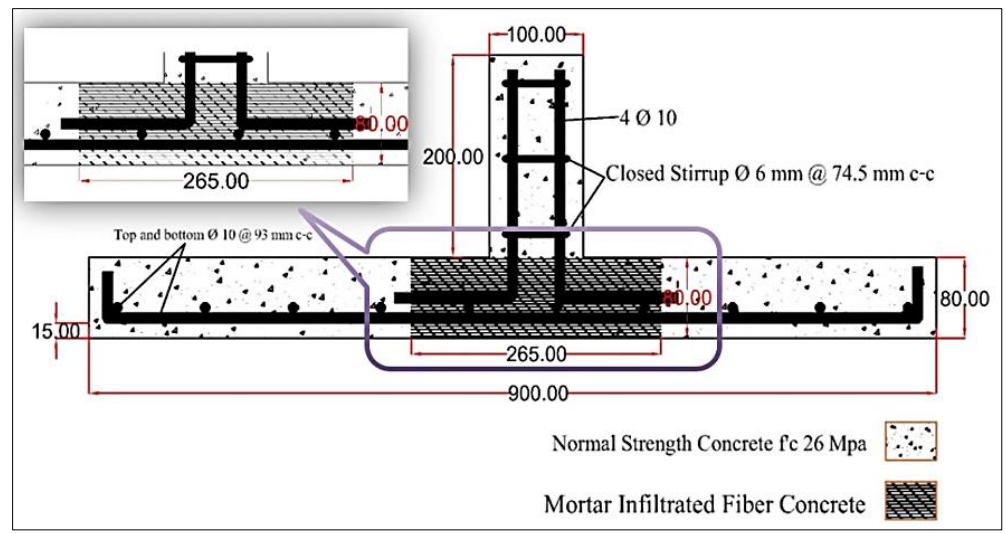

Figure 14. Cross section for slab showing the location of mortar infiltrated fiber concrete with $80 \mathrm{~mm}$ thickness. 

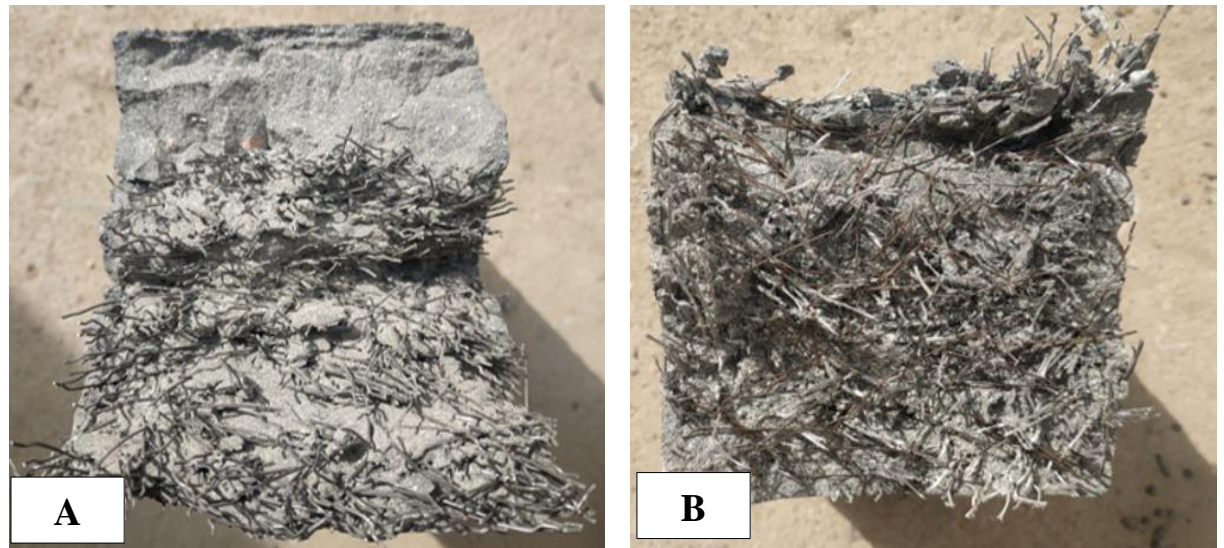

Figure 15. The cross section of failed prism shows the distribution of fiber A: steel fiber, B: hybrid fiber
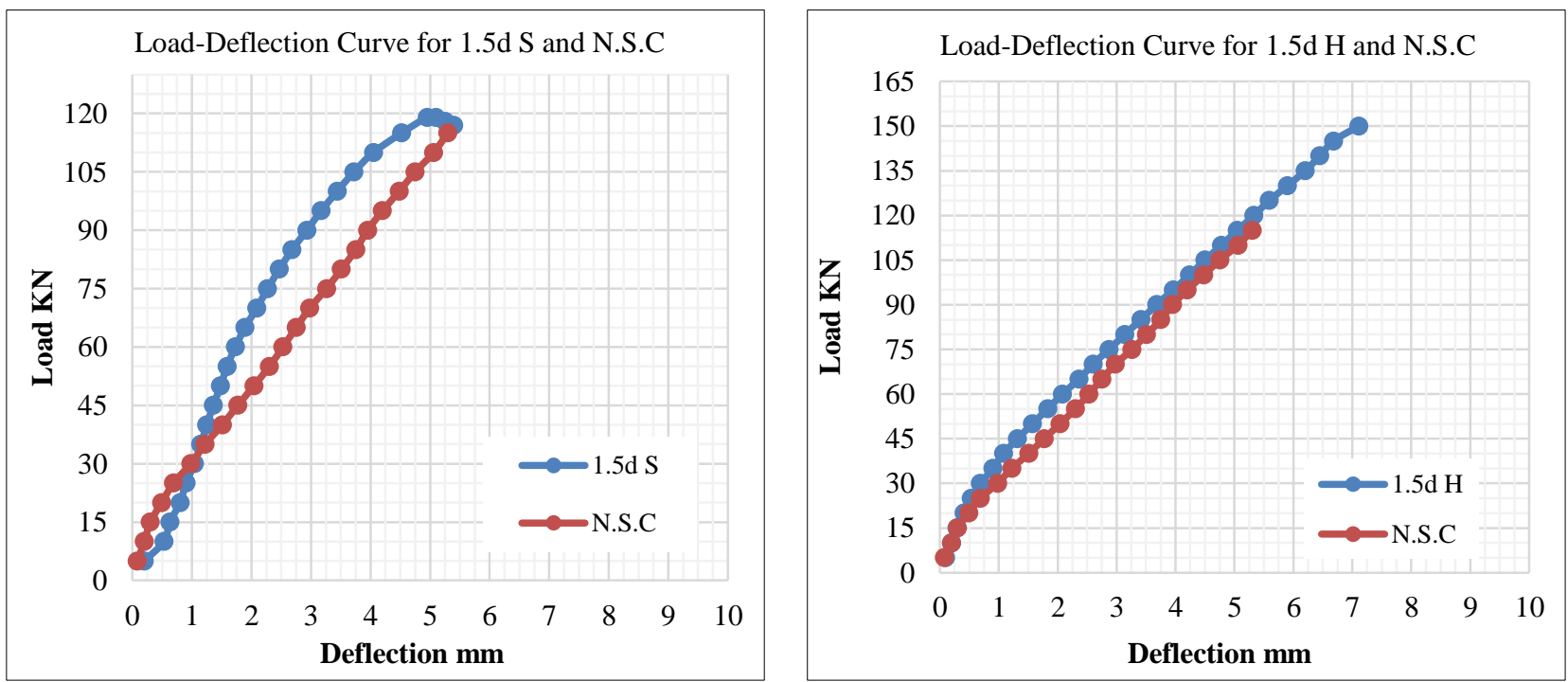

Figure 16. Load-Deflection curve for the two above cases compared with the reference
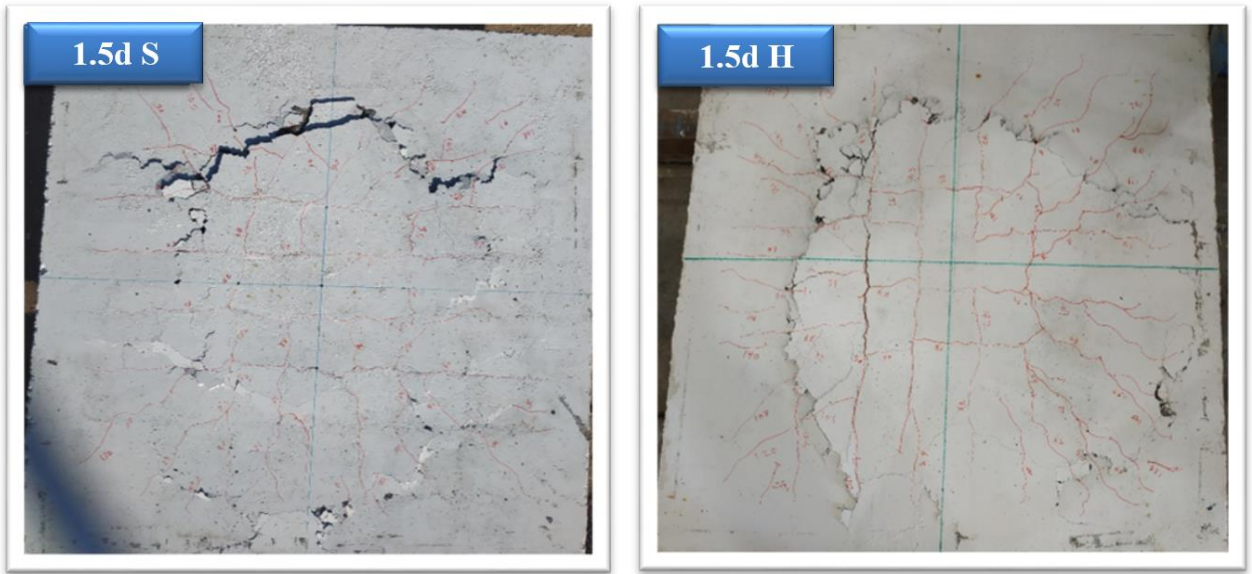

Figure 17. The final shape for tested slabs shows the crack pattern and punching perimeter

For the two remaining cases (1.5d S.C and 1.5d H.C) the mortar infiltrated fiber concrete cast with a thickness of $40 \mathrm{~mm}$ at the compression side directly under the column as shown in Figure 18. These cases gave excellent results in the ultimate load $12 \%$ and $46 \%$ respectively according to the type of fiber used in mortar infiltrated fiber concrete, using hybrid fiber gave better results from use steel fiber only. This variation in the results between these two cases is due to the distribution of fibers within the cross-section that was previously mentioned and shown in Figure 15 . Using mortar infiltrated fiber directly under column as in this specimens worked as a strong area compared with around region that led to distribute the load over a bigger area and faraway the load from the center towered the supports that lead to increase the ultimate load and deflection as shown in Figure 19. The shape of failure for these two slabs shown in Figure 20. 


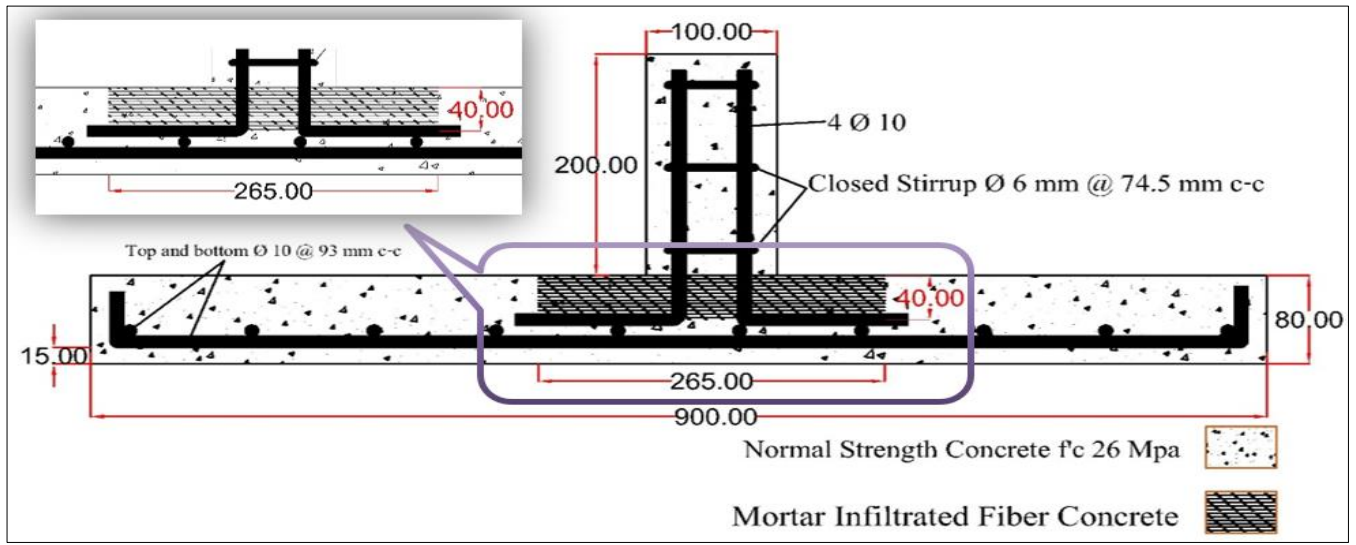

Figure 18. Cross section for slab showing the location of mortar infiltrated fiber concrete at the compression face
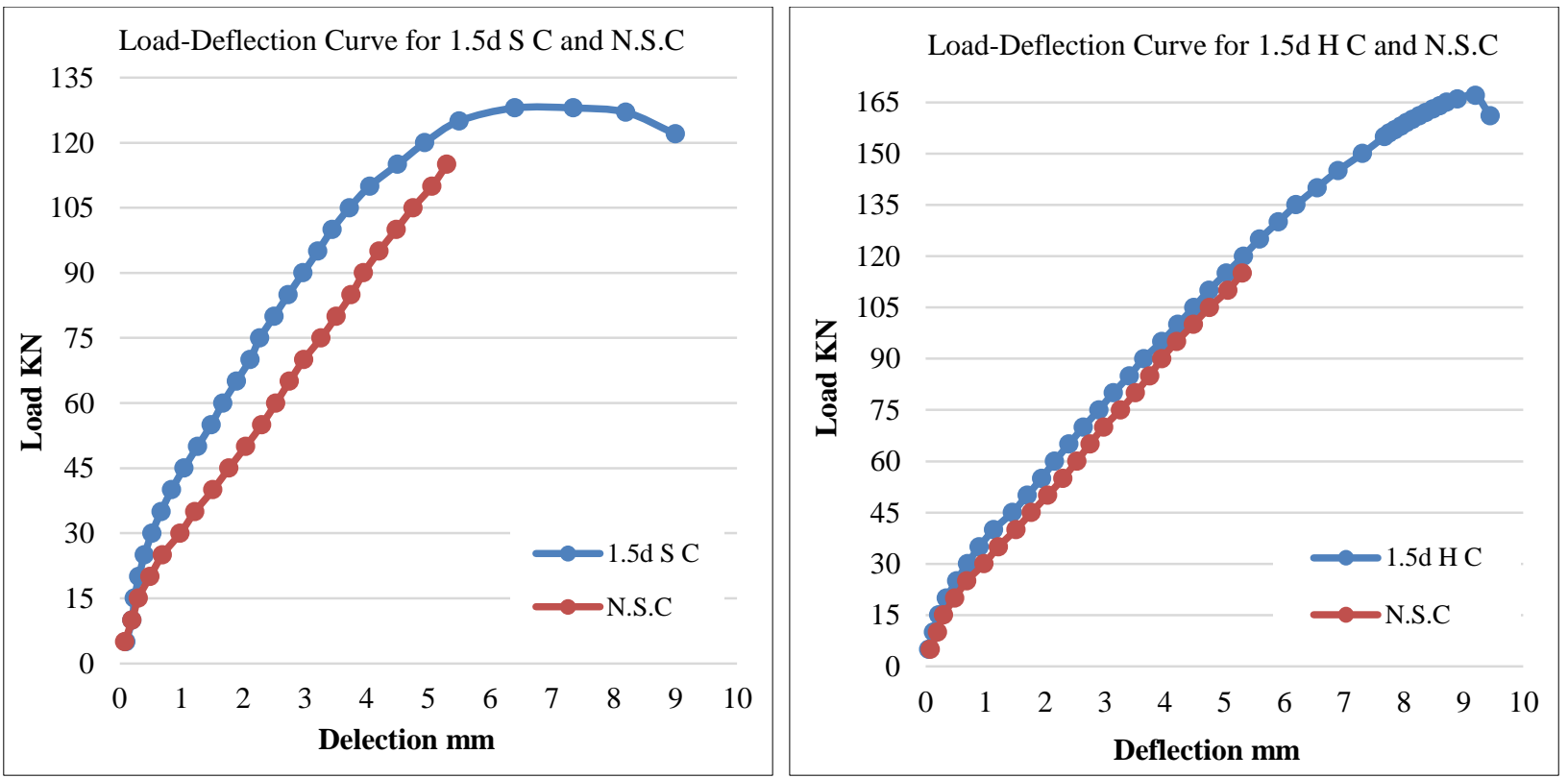

Figure 19. Load-Deflection curve for the last two cases compared with the reference
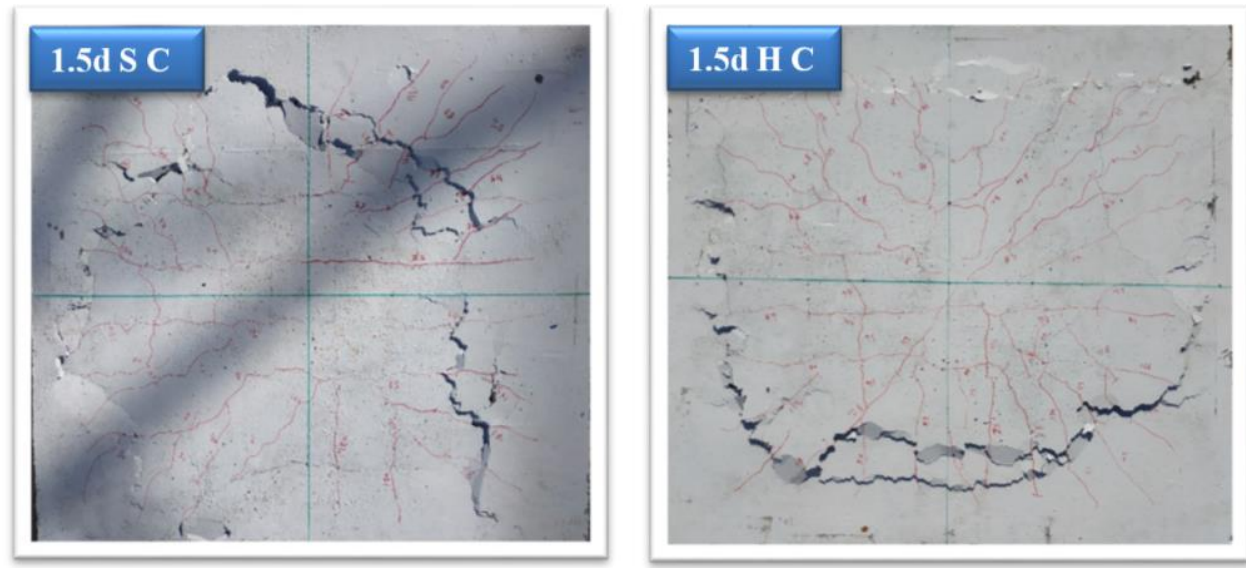

Figure 20. The final shape for tested slabs shows the crack pattern and punching perimeter

\section{Conclusions}

The punching shear strength of flat slabs strengthened with mortar-infiltrated fiber concrete was investigated in this study. Eight slabs-column connections were cast and tested under vertical load. The position and thickness of the mortar infiltrated fiber concrete, types of fibers submerged in mortar varied in different specimens. The following conclusions were drawn based on the test results: 
- Using mortar infiltrated fiber concrete, improves the punching shear strength of slabs for some cases according to the location of mortar infiltrated fiber concrete and the type of fiber used. The improvement percentage ranged from $4 \%$ to $46 \%$ with respect to the control specimen.

- Using mortar infiltrated fiber concrete, leads to increase deflection and change mode of failure from sadden to gradually failure.

- To the choice of the region, that cast with mortar infiltrated fiber concrete in slab large effect on improving punching shear and its amount.

- Using hybrid fiber in mortar have a significant impact through provide a perfect spread of fiber crossing the mortar infiltrated fiber concrete section.

- Casting mortar infiltrated fiber concrete with a half thickness of slab directly under the column at compression face, working on distributing the load on the bigger area and pushed away from the line of failure from the hometown of the column thus leads to increasing the ultimate load and deflection.

\section{Conflicts of Interest}

The authors declare no conflict of interest.

\section{References}

[1] American Concrete Institute. Building Code Requirements for Structural Concrete (ACI 318-14): Commentary on Building Code Requirements for Structural Concrete (ACI 318R-14): an ACI Report. American Concrete Institute. ACI, 2014.

[2] BS 1881 part 116, "Method for determination of compressive strength of concrete cube", British Standards Institutions, 1989.

[3] Gilani, Adel Mohamed, "Various durability aspects of slurry infiltrated fiber concrete." Ph.D Dissertation in Middle East Technical University, 2007. Available online: https://etd.lib.metu.edu.tr/upload/12608753/index.pdf (Accessed on: 10 Apr 2020).

[4] Dagar, Kuldeep. "Slurry infiltrated fibrous concrete (SIFCON)." International Journal of Applied Engineering and Technology 2, no. 2 (2012): 99-100.

[5] Deepesh, Patil, and Kanase Jayant. "Study of mechanical and durability properties of SIFCON by partial replacement of cement with fly ash as defined by an experimental based approach." International Journal for Innovative Research in Science \& Technology 5, no. 5 (2016).

[6] Rastegarian, Saeed, and Ashkan Sharifi. "An Investigation on the Correlation of Inter-Story Drift and Performance Objectives in Conventional RC Frames." Emerging Science Journal 2, no. 3 (July 9, 2018). doi:10.28991/esj-2018-01137.

[7] Farnam, Y., M. Moosavi, M. Shekarchi, S.K. Babanajad, and A. Bagherzadeh. "Behaviour of Slurry Infiltrated Fibre Concrete (SIFCON) Under Triaxial Compression." Cement and Concrete Research 40, no. 11 (November 2010):1571-1581. doi:10.1016/j.cemconres.2010.06.009.

[8] Pannem, Rama Mohan Rao, "Punching Strength and Impact Resistance Study of SIFCON with Different Fibres." International Journal of Civil Engineering and Technology (IJCIET) 8, no.4 (2017):1123-1131.

[9] H. Sudarsana Rao, N.V. Ramanab and K. Gnaneswarc "Behaviour of Restrained Sifcon Two Way Slabs Part 2: Punching Shear" Asian Journal of Civil Engineering (Building and Housing) Vol. 10, No. 4 (2009):481-494

[10] Jaafer, Abdulkhaliq Abdulyimah. "Experimental Investigation on the Ferrocement Slabs with a Sifcon Matrix." Wasit Journal of Engineering Sciences 3, no. 1 (March 9, 2015): 40-54. doi:10.31185/ejuow.vol3.iss1.34.

[11] Ali, M. A. "Properties of Slurry Infiltrated Fiber Concrete (SIFCON)." PhD diss., Ph.D. Thesis, civil engineering dep., UOT, Iraq, 2018.

[12] ACI Committee. "ACI 211.1-91 Standard Practice for Selecting Proportions for Normal, Heavyweight, and Mass Concrete, no. 9." Unites States (2002):120-121.

[13] Iraq Specification No.45, "Natural Sources for Gravel that is used in concrete and construction", Baghdad (1984).

[14] ASTM C33/86, Standard Specification for Concrete Aggregates.

[15] Giridhar, R., P. Rama, and M. Rao. "Determination of mechanical properties of slurry infiltrated concrete (SIFCON)." International Journal for Technological Research in Engineering 2, no. 7 (2015): 1366-1368. 
[16] Khamees, Shahad S., Mohammed M. Kadhum, and Nameer A. Alwash. "Effects of Steel Fibers Geometry on the Mechanical Properties of SIFCON Concrete.” Civil Engineering Journal 6, no. 1 (January 1, 2020): 21-33. doi:10.28991/cej-202003091450 .

[17] Krishnan, M Gopala, D Elavarasi, "Experimental study on slurry infiltrated fibrous concrete with sand replaced by Msand." International Journal of Engineering Research \& Technology 3, no. 5 (2014): 534-537.

[18] ASTM C494/C494M, Standard Specification for Chemical Admixtures for Concrete, 2017.

[19] ASTM A820 / A820M - 16 Standard Specification for Steel Fibers for Fiber-Reinforced Concrete.

[20] ASTM A615 / A615M-16, Standard Specification for Deformed and Plain Carbon-Steel Bars for Concrete Reinforcement, ASTM International, West Conshohocken, PA, 2016, www.astm.org.

[21] Hashim, Ali Mudhafar, and Mohammed Mansour Kadhum. "Compressive Strength and Elastic Modulus of Slurry Infiltrated Fiber Concrete (SIFCON) at High Temperature.” Civil Engineering Journal 6, no. 2 (February 1, 2020): $265-275$. doi:10.28991/cej-2020-03091469.

[22] E. Rizk, H. Marzouk, A. Hussein, and M. Hossin "Punching Shear of Thick Plates with and Without Shear Reinforcement." ACI Structural Journal 108, no. 5 (2011). doi:10.14359/51683215. 